\title{
PENGGUNAAN VIDEO ANIMASI EXPLAINER SEBAGAI MEDIA PEMBELAJARAN (Studi Kasus: Madrasah Aliyah 2 Sambas )
}

\author{
Salahuddin ${ }^{1 *}$, Asbeni $^{1}$ \\ ${ }^{1}$ Jurusan MANAJEMEN INFORMATIKA, Prodi TEKNIK MULTIMEDIA, Politeknik Negeri \\ ${ }^{2}$ Jurusan MANAJEMEN INFORMATIKA, Prodi TEKNIK MULTIMEDIA, Politeknik Negeri \\ Sambas \\ Jl. Raya Sejangkung, Kabupaten Sambas, Kalimantan Barat 79462. \\ "Email: salahuddin33168@gmail.com
}

\begin{abstract}
Abstrak
Fokus penelitian pada mata pelajaran Geografi kelas XI Madrasah Aliyah Negeri (MAN) Sambas. Berdasarkan hasil observasi pada tanggal 24-25 Februari 2018 diketahui bahwa, kegiatan pembelajaran Geografi di MAN Sambas belum memanfaatkan media pembelajaran berbasis Multiedia. Terdapat empat orang guru yang mengajar mata pelajaran Geografi. Dua orang guru menggunakan media Power Point, dan media cetak dari surat kabar, sedangkan dua orang guru lainnya menggunakan metode konvensional berupa ceramah dan diskusi tanpa menggunakan media pembelajaran. Keikutsertaan siswa dalam proses pembelajaran Geografi sebatas mendengarkan, menyimak, mencatat, latihan soal,. Respon siswa dalam proses pembelajaran selama ini cenderung baik. Akan tetapi siswa lebih antusias ketika proses pembelajaran menggunakan bantuan media pembelajaran berbasis multimedia. Penelitian ini fokus pada pengembangan dan uji kelayakan produk untuk pengoptimalan penggunaan media pembelajaran. Media pembelajaran yang dikembangkan berbasis komputer berupa video animasi explainer. Model penelitian yang digunakan adalah model penelitian dan pengembangan atau sering disebut sebagai Research and Development (R\&D). Data hasil observasi dan wawancara pendahuluan termasuk dalam kategori data kualitatif data kuantitatif berasal dari kuesioner penelitian. Data dari kuesioner dianalisis dengan statistik deskriptif, selanjutnya dikonversi dalam data kualitatif skala Likert. Penilaian kelayakan produk dalam penelitian ini ditetapkan minimal C atau "Cukup". Jika dari para ahli materi, para ahli media, para guru, dan para siswa memberikan nilai minimal tersebut, maka produk hasil pengembangan ini dinyatakan layak untuk digunakan dalam pembelajaran.Hasil dari penelitiaan adalah berupa produk Video Animasi explainer merupakan salah satu media pembelajaran pendukung yang dibuat dalam bentuk soft copy. Materi dalam media pembelajaran yang dikembangkan disusun berpedoman pada Kurikulum 2013.
\end{abstract}

Kata kunci: Animasi Explainer, Geografi, Media Pembelajaran,

\section{PETUNJUK UMUM}

Media Pembelajarab memberikan alternafif bagi para guru dalam melakukan proses belajar mengajar, dengan menerafkan teknologi dalam melakukan pengembangan pembelajaran dikelas. Melalui media pembelajaran, materi pembelajaran diharapkan mampu lebih menarik, efisien, dan efektif. Madrasah Aliyah Negeri (MAN) Sambas merupakan salah satu sekolah setingkat Sekolah Menengah Atas (SMA) yang berada di bawah kantor Kementerian Agama (KEMENAG).
MAN Sambas beralamat di Jl. Raya Sejangkung Desa Sebayan Kab Sambas. Berdasarkan hasil observasi pada tanggal 24-25 Februari 2018 diketahui bahwa, kegiatan pembelajaran Geografi di MAN Sambas belum semua guru geografi memanfaatkan media pembelajaran yang sudah tersedia di sekolah secara optimal. Terdapat empat orang guru yang mengajar mata pelajaran Geografi. Dua orang guru menggunakan media Power Point, dan media cetak dari surat kabar, sedangkan dua orang guru lainnya menggunakan metode 
konvensional berupa ceramah dan diskusi tanpa menggunakan media pembelajaran. Proses pembelajaran yang dilakukan di MAN Sambas hanya bersifat transfer ilmu saja. Keikutsertaan siswa dalam proses pembelajaran Geografi sebatas mendengarkan, menyimak, mencatat, latihan soal, beberapa kali dengan penugasan di dalam dan luar kelas, serta diskusi kelompok. Respon siswa dalam proses pembelajaran selama ini cenderung baik dalam menerima materi pelajaran dari guru, dan melaksanakan penugasan-penugasan. Akan tetapi siswa lebih antusias ketika proses pembelajaran menggunakan bantuan media pembelajaran. Melalui penggunaan media pembelajaran diharapkan guru mampu menyampaikan materi secara lebih efektif.

Fokus penelitian peneliti pada mata pelajaran rumpun ilmu sosial ekonomi kelas X. Peneliti berdiskusi dengan Ibu Khairunnisa, S. Pd. selaku guru mata pelajaran geografi yang menggunakan media pembelajaran berbasis ICT di dalam kelas yang diampunya. Ibu Khairunisa menuturkan bahwa, bantuan media sangat membantu siswa dalam memahami materi, hal ini tentu menjadi masalah bagi siswa, mengingat mereka harus menguasai materi dengan cepat dan benar. Ibu Khairunisa menyarankan peneliti untuk mengembangkan media pembelajaran yang dikategorikan bersifat konseptual dan abstrak untuk divisualisasikan. Sehingga melalui bantuan media pembelajaran, materi manajemen diharapkan menjadi mudah untuk diterima siswa. Sesuai yang peneliti uraikan diatas, untuk mengatasi permasalahan , penulis memberikan solusi membuat media yang dikembangkan berupa video animasi explainer (penjelasan). Media dikembangkan menggunakan beberapa software, yaitu: Adobe Illustrator CC 2015, Adobe After Effects CC 2015, Gimp 2.8, Anime Studio Pro, Audacity ,Ink Scape.

\section{METODOLOGI}

\section{Penulisan Persamaan}

Model penelitian yang digunakan dalam penelitian ini adalah model penelitian dan pengembangan atau sering disebut sebagai Research and Development (R\&D). Menurut Endang Mulyatiningsih (2014: 161), model penelitian dan pengembangan bertujuan untuk menghasilkan produk baru melalui proses pengembangan. Kegiatan penelitian diintegrasikan selama proses pengembangan produk. Proses penelitian dan pengembangan dimulai dengan menghasilkan produk berdasarkan temuan uji di lapangan, kemudian divalidasi oleh para ahli. Menurut W. R. Brog dan M. D. Gall (dalam Punaji Setyosari, 2015: 276), penelitian dan pengembangan adalah proses untuk mengembangkan dan memvalidasi produk pendidikan, tahapan-tahapannya adalah sebagai berikut. Pertama, mengkaji dan menganalisis kebutuhan dari produk yang dikembangkan. Kedua, mengembangkan produk berdasarkan temuan-temuan tersebut. Ketiga, melakukan serangkaian validasi dan uji coba dengan latar tempat yang sama ketika produk tersebut akan digunakan. Keempat, melakukan revisi terhadap hasil validasi dan uji coba. Penelitian yang dilakukan oleh peneliti menggunakan rujukan dari Dick\&Carey dalam model The Systematic Design of Instruction. Menurut Muhammad Atwi Suparman (2014: 5), model The Systematic Design of Instruction memiliki beberapa kelebihan sebagai berikut. Pertama, alur pelaksanaan model jelas untuk dilaksanakan. Kedua, arahan diatur dengan simbol tanda panah dan garis putus-putus untuk umpan balik. Ketiga, sistematis, mudah dicerna, dan mudah diikuti. Keempat, relevan diterapkan untuk praktik instruksional. Kelima, penggunaan model ini terus meluas di seluruh dunia. Keenam, langkah-langkahnya logis dan praktis dari tahap awal sampai tahap akhir. Ketujuh, keteraturan ini mampu menciptakan sistem atau produk instruksional yang efektif dan efisien.

Model prosedural Dick\&Carey (1978: 9) terdapat 10 tahap. Tahapan-tahap tersebut sebagai berikut. Pertama, analisis kebutuhan dan tujuan pembelajaran. Kedua, analisis pembelajaran. Ketiga, analisis pembelajar (siswa) dan konteks. Keempat, merumuskan tujuan performansi atau unjuk kerja. Kelima, mengembangkan instrumen atau alat tes. Keenam, mengembangkan strategi pembelajaran. Ketujuh, mengembangkan dan memilih bahan pembelajaran. Kedelapan, merancang dan melakukan evaluasi formatif. Kesembilan, melakukan revisi. Kesepuluh, melakukan evaluasi sumatif.

Subjek yang melakukan validasi dan uji coba dalam penelitian ini terdiri dari para ahli, para guru, para siswa. Validasi dilakukan oleh ahli materi dan ahli media. ahli media adalah dosen program studi Teknik Multimedia Politeknik Negeri Sambas. Selanjutnyaahli 
materi di validasi kepada guru mata pelajaran Geografi di MAN Sambas. Uji coba dilakukan kepada beberapa siswa kelas X peminatan IPS MAN Sambas.

Pengumpulan data dalam penelitian pengembangan ini dilakukan melalui observasi, wawancara (interview), kuesioner (angket), dan dokumentasi. Menurut Sugiyono (2014: 203), observasi sebagai teknik pengumpulan data mempunyai ciri yang spesifik dibandingkan dengan teknik lain. Penelitian ini menggunakan teknik observasi partisipan terstruktur. Observasi dilakukan dengan menggunakan pedoman sebagai instrumen pengamatan. Dalam penelitian pendahuluan yang diamati adalah pelaksanaan kegiatan belajar mengajar mata pelajaran geografi oleh guru di MAN Sambas dan ketika uji coba produk. Observasi untuk mengamati respon siswa saat kegiatan pembelajaran ekonomi dan uji coba produk berlangsung. Menurut Nasution (2003: 113), wawancara merupakan teknik mendapatkan data melalui pemograman verbal dengan responden. Wawancara digunakan untuk mengetahui penggunaan media pembelajaran di sekolah dan menentukan materi yang akan dikembangkan dalam video animasi explainer. Menurut Sugiyono (2014: 199), kuesioner merupakan teknik yang dilakukan dengan cara memberikan seperangkat pertanyaan atau pernyataan tertulis kepada responden. Lembar kuesioner terdiri dari beberapa aspek penilaian, komentar, dan saran. Instrumen penelitian ini berupa kuesioner tertutup. Kuesioner bertujuan untuk menilai kelayakan video animasi explainer berdasarkan aspek pembelajaran, isi materi, komponen video, tampilan dan penyajian, pemrograman, dan suara..

Instrumen pengumpulan data merupakan alat bantu untuk mengumpulkan data penelitian melalui pengukuran. Pada prinsipnya penelitian adalah pengukuran, maka harus ada alat ukur. Menurut Gulo (dalam Eko Putro Widoyoko, 2012: 51), instrumen penelitian merupakan pedoman tertulis tentang wawancara, pengamatan, dan daftar pertanyaan untuk mendapatkan informasi. Instrumen penelitian bertujuan mengevaluasi dan mengetahui kelayakan media. Instrumen untuk mengumpulkan data berupa kuesioner, berisi beberapa aspek, komentar, dan saran yang dibagi tiga kelompok. Meliputi instrumen uji kelayakan ahli materi dan ahli media,
Pengembangan Media Pembelajaran serta uji empirik untuk guru dan siswa. Instrumen untuk siswa dan guru meliputi isi materi, pembelajaran, desain tampilan dan penyajian, suara. Kuesioner digunakan untuk mengumpulkan pendapat dari validator dan guru-guru mata pelajaran ekonomi di MAN Sambas. Mengumpulkan pendapat para siswa kelas X peminatan IPS dalam uji coba produk. Kuesioner menggunakan skala Likert lima. Proses analisis data menggunakan pendekatan kualitatif dan kuantitatif. Data yang termasuk dalam kategori kualitatif berasal dari komentar dan saran para validator dan responden. Selanjutnya disarikan sebagai masukan untuk memperbaiki dan merevisi produk media yang dikembangkan. Data hasil observasi dan wawancara pendahuluan termasuk dalam kategori data kualitatif. Data kuantitatif berasal dari kuesioner penelitian. Data dari kuesioner dianalisis dengan statistik deskriptif, selanjutnya dikonversi dalam data kualitatif skala Likert. Setiap item pertanyaan diberi bobot 5 (sangat baik), 4 (baik), 3 (cukup), 2 (kurang baik), dan 1 (tidak baik). Penilaian kelayakan produk dalam penelitian ini ditetapkan minimal C atau "Cukup". Oleh karena itu, jika dari para ahli materi, para ahli media, para guru, dan para siswa memberikan nilai minimal tersebut, maka produk hasil pengembangan ini dinyatakan layak untuk digunakan dalam pembelajaran.

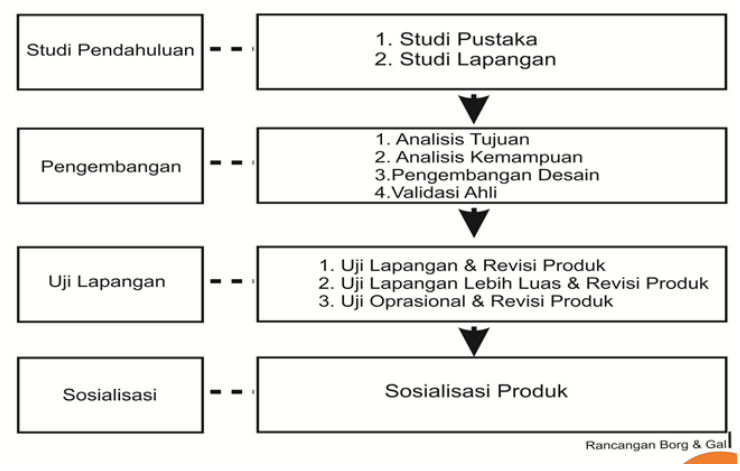

Gambar 1. Metode Penelitian Research and Development (R\&D)

\section{HASIL DAN PEMBAHASAN}

Sesuai yang peneliti uraikan diatas, untuk mengatasi permasalahan, penulis memberikan solusi membuat media berbasis multimedia yang dikembangkan berupa video animasi explainer (penjelasan). Media dikembangkan menggunakan beberapa software, yaitu: Adobe 
Illustrator CC 2015, Adobe After Effects CC 2015, Gimp 2.8, Anime Studio Pro, Audacity ,Ink Scape.

Menghasilkan produk baru melalui proses pengembangan. Kegiatan penelitian diintegrasikan selama proses pengembangan produk. Proses penelitian dan pengembangan dimulai dengan menghasilkan produk berdasarkan temuan uji di lapangan

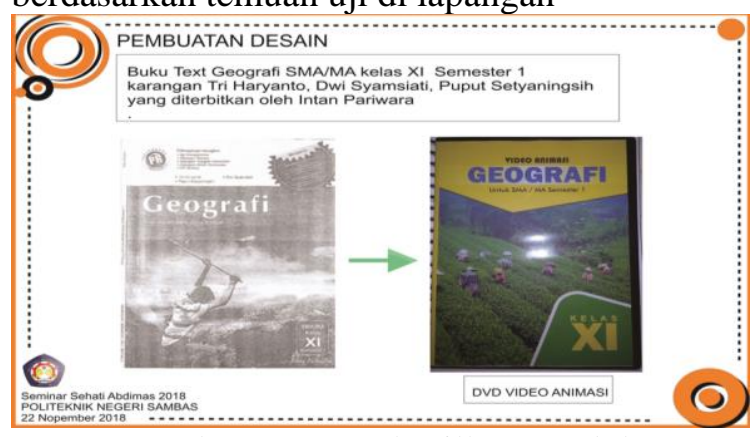

Gambar 2. Menghasilkan Produk Pengembangan

Tabel 1. Pedoman konversi data kuantitatif ke data kualitatif

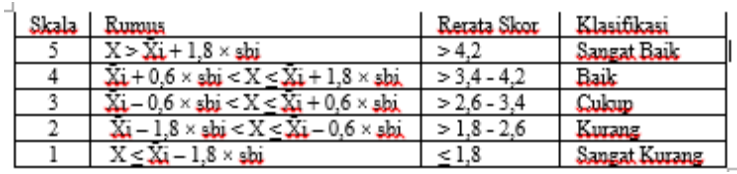

Tabel 2. Penilai indikator skala Likert

\begin{tabular}{|c|c|}
\hline Angka & Nilai Mutu \\
\hline 1 & Sangat Kurang \\
\hline 2 & Kurang \\
\hline 3 & Cukup \\
\hline 4 & Baik \\
\hline 5 & sangat Baik \\
\hline
\end{tabular}

Data dari kuesioner dianalisis dengan statistik deskriptif, selanjutnya dikonversi dalam data kualitatif skala Likert. Setiap item pertanyaan diberi bobot 5 (sangat baik), 4 (baik), 3 (cukup), 2 (kurang baik), kuesioner diberikan kepada ahli media untuk dinilai. Subjek yang melakukan validasi dan uji coba dalam penelitian ini terdiri dari para ahli, para guru, para siswa. Validasi dilakukan oleh ahli materi dan ahli media. ahli media adalah dosen program studi Teknik Multimedia Politeknik Negeri Sambas. Selanjutnya ahli materi di validasi oleh guru mata pelajaran Geografi di MAN Sambas. Uji coba dilakukan kepada beberapa siswa kelas IX MAN Sambas.

\section{Tabel 3. Hasil Penilaian Ahli Media}

\begin{tabular}{|c|c|c|c|}
\hline \multicolumn{2}{|c|}{ Hasil Renilaian Ahli Media } & \multirow[b]{2}{*}{ Skor } & \multirow[b]{2}{*}{ Kriteria } \\
\hline No & Butir Renilaian & & \\
\hline 1 & ciri khas tokob cerita & 3 & cukup \\
\hline 2 & Jauran dan bentuk media & 5 & gangat baik \\
\hline 3 & Mudah dibauca & 5 & sangat baik \\
\hline 4 & Baban aman digunakan untuk siswa & 3 & baik \\
\hline 5 & Kualitas catak & 4 & baik \\
\hline 6 & Daya tahan/keawetan media & 4 & baik \\
\hline 7 & Mengandung nilai estetika & 3 & baik \\
\hline 8 & Belajar sigua lebih menvenangkan & 4 & baik \\
\hline 9 & Tata letak desain sampul & 4 & baik \\
\hline 10 & Eiliban warna desain samopul & 5 & sangat baik \\
\hline 11 & Kesesuaian sambar ilustrasi desain sampul & 3 & culoup \\
\hline 12 & Jlouran dan jevis huruf desain sampul & 4 & baik \\
\hline 13 & Tata letak ilustrasi isicerita & 3 & cukup \\
\hline 14 & Riliban uama ilustrati isi cerita & 3 & cukoup \\
\hline 15 & Kesesuaian gambar ilustrasi ilustrasi isi cerita & 4 & baik \\
\hline 16 & Shouran dan ievis huruf ilustrasi iri cerita & 5 & gangat baik \\
\hline 17 & Memotivasi sianca & 4 & baik \\
\hline 18 & Mempermudah sisua mengingat materi & 3 & culup \\
\hline 19 & Renxajian media membuat materi lebih menarik & 5 & sangat baik \\
\hline \multirow[t]{3}{*}{20} & Mudah digunakan & 5 & gangat baik \\
\hline & total & 79 & \\
\hline & rata-rata & 3,95 & \\
\hline
\end{tabular}

Tabel 4. Hasil Penilaian Ahli Materi

\begin{tabular}{|c|c|c|c|}
\hline \multicolumn{2}{|c|}{ Hasil Revilaian Ahi Alateri. } & \multirow[b]{2}{*}{ Skor } & \multirow[b]{2}{*}{ Kriteria } \\
\hline No & Butir Renilaian & & \\
\hline 1 & $\begin{array}{l}\text { Materi yang disajikan sesuai dengan standat } \\
\text { kompetensi. }\end{array}$ & 4 & baik \\
\hline 2 & Rumusan tujuan pembelajaran sesuai & 4 & baik \\
\hline 3 & Kesesurian alur cerita & 4 & sangat baik \\
\hline 4 & Kesesuaian ilustrasi gambar & 5 & sangat baik \\
\hline 5 & Kesesuraian dilaog dengan peristiva & 3 & culaup \\
\hline 6 & Ketepatan setting cerita & 3 & culaup \\
\hline 7 & Ketepatan penulisan & 4 & baik \\
\hline 8 & Renyajijan materi runtut. & 5 & sangat baik \\
\hline 9 & Membantu sisva memahami materi & 4 & baik \\
\hline 10 & Membantu sisuca mengingat alur materi & 3 & culup \\
\hline 11 & Rangkuman dinvatakan secara ringka5 & 3 & culaup \\
\hline 12 & $\begin{array}{l}\text { Rangkuman memudahkan sisua memahawi } \\
\text { materi }\end{array}$ & 5 & sangat baik \\
\hline 13 & Bahasa paudah dipahamai siavua & 4 & baik \\
\hline 14 & Andah dalam pengerupanuxa bagi sisua & 5 & sangat baik \\
\hline 15 & Mudah dalam pengeuvaanuya bagi guru & 5 & sangat baik \\
\hline 16 & Bisa digunakan sendiri di luar kelas & 5 & sangat baik \\
\hline 17 & Mengalatifkan emogi sianca & 3 & culup \\
\hline 18 & Bisa meningkatkan motivasi belajar. & 4 & baik \\
\hline 19 & Meningkatkan suka menggambar & 4 & baik \\
\hline \multirow[t]{3}{*}{20} & Kesesuaian exaluasi dengan indikatox. & 3 & cukup \\
\hline & total & 80 & \\
\hline & rata-rata & 4 & baik \\
\hline
\end{tabular}


Hasil dari penilaian para ahli dilihat dari garfik sbb

\section{Tabel 5. Grafik Penilai Ahli}

\section{HASIL PENILAIAN AHLI}

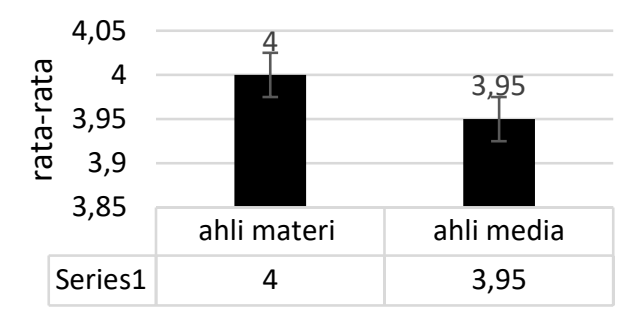

Dalam proses validasi diberikan penilai oleh ahli materi dan ahli media, masing- masing para ahli memberikan penilian untuk ahli materi rata-rata 4 dan nilai untuk ahli media rata-rata 3,95. Dalam tabel konversi data kuantitatif ke data kualitatif termasuk dalam interval $>3,4$ 4,2 sehingga termasuk dalam kategori "baik". Berdasarkan ketentuan penelitian bahwa produk media dikatakan layak apabila minimal termasuk dalam kategori baik, maka produk media telah layak dari segi pertimbangan media. Hal tersebut diperkuat dengan pernyataan ahli media bahwa produk media yang dikembangkan telah layak diujicobakan Tahapan selanjutnya adalah uji Lapangan artinya melakukan penilaian kuesoner terhadap ratarata penilaian siswa. Uji coba dilakukan dalam tiga tahap, yakni uji lapangan terbatas, uji lapangan lebih luas, dan uji operasional.

\section{Tabel 6. Grafik Penilai Uji Lapangan}

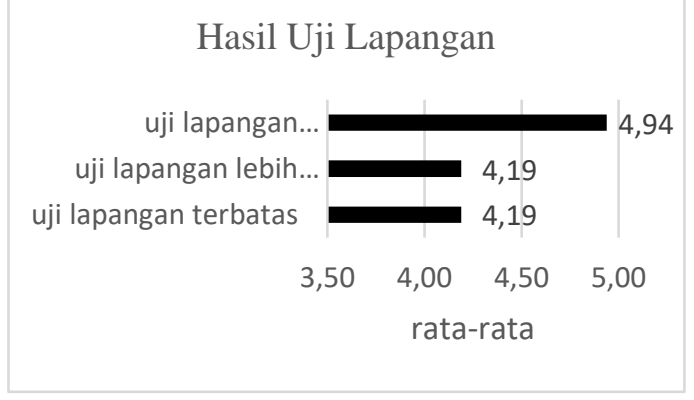

Dari hasil penilain uji lapangan didapatkan hasil uji lapangan mengunakan teknik sampling yang dipakai dalam tahap ini adalah purposive sampling (teknik sampling bertujuan). Purposive sampling adalah cara pengambilan sampel yang berdasarkan pada pertimbangan dan atau tujuan tertentu. Sebagai subjek uji lapangan terbatas, sampel dalam tahap ini diambil tiga orang siswa dengan tingkat intelektual tinggi, sedang, dan rendah khususnya dalam pada pelajaran geografi. Subjek uji lapangan lebih luas sampel dalam tahap ini diambil enam orang siswa dengan tingkat intelektual tinggi, sedang, dan rendah. Subjek uji lapangan oprasional, sampel dalam tahap ini diambil satu kelas khususnya dalam pada pelajaran geografi . Masing - masing hasil dari uji lapangan terbatas adalah 4,19, hasil dari uji lapangan lebih luas adalah 4,19 , hasil dari uji lapangan oprasional adalah 4,94. Menurut pedoman konversi data kuantitatif ke kualitatif perolehan rata-rata berada pada interval $>3,4-$ 4,2 sehingga termasuk kriteria "baik".

Dengan demikian produk video pembelajaran hasil pengembangan dari buku ajar layak di gunakan karna berdasarkan ketetapan bahwa produk media dikatakan layak apabila hasil penilaian minimal pada kriteria baik.

\section{SIMPULAN}

Berdasarkan yang telah diuraikan, dapat ditarik kesimpulan bahwa media ajar dalam bentuk video animasi dapat dibuat bedasarkan buku ajar /buku utama sebagai buku pendamping mata pelajaran geografi IPS MAN Kelas IX.Video animasi explainer dikatakan layak digunakan untuk pembelajaran yang sifatnya sebagai buku pendamping / alternatif dirasakan mampu menumbuhkan minat belajar siswa.

\section{UCAPAN TERIMA KASIH}

Alhamdulillahirobbil'alamin segala puji hanya bagi Allah SWT, Tuhan seluruh alam semesta karena berkat rahmat, taufik dan hidayah-Nya penulis dapat menyelesaikan Penelitian ini. Penelitian ini disusun dalam rangka Program Penelitian Dosen Poltesa demi mewujudkan tridarma perguruan tinggi agar menjadi referensi penelitian yang akan datang.

Peneliti menyadari tanpa adanya dukungan dan kerja sama dari berbagai pihak, kegiatan penelitian ini tidak akan dapat berjalan baik. Untuk itu, penulis sampaikan rasa terima 
kasih dan penghargaan setinggi-tingginya kepada semua pihak yang terkait. handbook, (5) makalah dalam sebuah chapter buku, (6) desertasi, dan (7) paten.

\section{DAFTAR PUSTAKA}

Jurnal:

Adinugraha.Y, dkk.2016. Pengembangan Aplikasi Komik Hadits Berbasis Multimedia. Jurnal Jurnal Algoritma Sekolah Tinggi Teknologi. ISSN : 23027339 Vol. 13 No. 12016

Sulfiah. U dan Sulisworo. D. 2016. Pengembangan Media Pembelajaran Kontekstual Menggunakan Komik Fisika Untuk Peserta Didik Smp/Mts Kelas Vii Pada Pokok Bahasan Kalor. Jurnal berkala Fisika Indonesia Vol 8 Nomor 2.

Buku:

Sunarso dan Anis Kusuma Ilmu Pengetahuan Sosial Untuk SD dan MI Kelas III. Jakarta : pusat pembukuan Departemen Pendidikan Nasional. 2008

Hendratman, H. Computer Of Graphic Design. Jakarta: Informatika.2017

Hendratman, H. The Magic Of Corel Draw. Jakarta: Informatika.2017

Skripsi, Tesis, Disertasi:

Supriyanta, E.Y. 2015. Pengembangan Media Komik Untuk Mata Pelajaran Ilmu Pengetahuan Sosial Tentang Sejarah Persiapan Kemerdekaan Indonesia Pada Kelas V SD Muhammadiyah Mutihanwates Kulon Progo (Skripsi). Juruan Prasekolah dan Sekolah Dasar. UNY. Yogyakarta.

Mulyani, T. 2009. Efektivitas Penggunaan Media Komik Strip Pada Pembelajaran Materi Saling Ketergantungan Dalam Ekosistem Di Smp Negeri 1 Kaliwungu Kudus (Skripsi). Jurusan Biologi. UNS. Semarang. 